\title{
Aqueous Phosphate Removal and Electricity Production Using an Iron-Air Fuel Cell
}

\author{
Changyu $\mathrm{Li}^{1}$ and Yanqing Sheng ${ }^{2}$
}

\begin{abstract}
Phosphorus (P) surplus is a key factor in water eutrophication, and aqueous phosphate removal is a concern. In this study, ferrous ions $\left(\mathrm{Fe}^{2+}\right)$ were generated in situ by iron-air fuel cells and were used in the removal of $\mathrm{P}$ from synthetic P-containing wastewater. The $\mathrm{P}$ removal results indicated that different initial concentrations of $\mathrm{P}$ were more effectively removed by an in situ Fe ${ }^{2+}$ generation than by the addition of $\mathrm{FeSO}_{4}$. The main $\mathrm{P}$ removal products of $\mathrm{FeSO}_{4}$ were Fe hydroxides, whereas the main products with the iron fuel cell were vivianite and $\mathrm{Fe}$ hydroxides. These results suggested that $\mathrm{Fe}^{2+}$ formed in situ had a more conducive and stronger affinity to bond phosphate than $\mathrm{FeSO}_{4}$. The maximum power density reached $1,875 \mathrm{~mW} / \mathrm{m}^{2}$ after $24 \mathrm{~h}$ of operation. The results indicate that the iron-air fuel cell can be used for P removal/recovery coupled with potential electricity generation. DOI: 10.1061/(ASCE)EE.1943-7870.0001724. (C) 2020 American Society of Civil Engineers.
\end{abstract}

\section{Introduction}

Phosphorus $(\mathrm{P})$ is an essential element for living organisms in aqueous ecosystems. However, the excessive emissions of P from agriculture and human activity have caused increasing crises such as eutrophication in aquatic environments (Conley et al. 2009). For $\mathrm{P}$ removal, the popular techniques are enhanced biological $\mathrm{P}$ removal and chemical $\mathrm{P}$ removal using $\mathrm{Fe}$ or aluminum salts (Wilfert et al. 2015). However, biological P removal technologies suffer from low efficiency when treating wastewater containing high concentrations of P. Based on their cost and efficiency, Febased technologies for $\mathrm{P}$ removal have received more attention (Molinos-Senante et al. 2011).

Currently, Fe salts are regarded as the most common method of $\mathrm{Fe}$ dosing. However, $\mathrm{Fe}$ dosing by zero-valent iron (ZVI) and $\mathrm{Fe}^{2+}$ generated in situ also have attracted attention for their high efficiency. Previous reports have shown that the addition of $\mathrm{Fe}$ salts (e.g., $\mathrm{FeSO}_{4}$ and $\mathrm{FeCl}_{3}$ ) can enhance $\mathrm{P}$ removal during wastewater treatment (Zhou et al. 2008; Ren et al. 2019). However, the associated anions may lead to scale formation and corrosion (Zhang et al. 2018). Furthermore, the dosage of Fe salts decreases the aqueous $\mathrm{pH}$, and neutralization might be required prior to discharge. $\mathrm{P}$ can be effectively absorbed by ZVI for P removal (Almeelbi and Bezbaruah 2012; Sleiman et al. 2016). However, passivation prevents its reactivity due to the formation of Fe oxides on the surface, resulting in the unsustainability of the ZVI technology (Wan et al.

${ }^{1} \mathrm{Ph} . \mathrm{D}$. Student, Research Center for Coastal Environment Engineering Technology of Shandong Province, Yantai Institute of Coastal Zone Research, Chinese Academy of Sciences, Chunhui Rd. 17, Laishan District, Yantai 264003, PR China; College of Resources and Environment, Univ. of Chinese Academy of Sciences, No. 19(A) Yuquan Rd., Shijingshan District, Beijing 100049, PR China. Email: cyli@yic.ac.cn

${ }^{2}$ Professor, Research Center for Coastal Environment Engineering Technology of Shandong Province, Yantai Institute of Coastal Zone Research, Chinese Academy of Sciences, Chunhui Rd. 17, Laishan District, Yantai 264003, PR China (corresponding author). Email: yqsheng@yic .ac.cn

Note. This manuscript was submitted on October 11, 2019; approved on January 2, 2020; published online on April 8, 2020. Discussion period open until September 8, 2020; separate discussions must be submitted for individual papers. This paper is part of the Journal of Environmental Engineering, (C) ASCE, ISSN 0733-9372.
2018). Although nanosized sorbents have a favorable sorption capacity and removal rate, separation still is difficult, and there are concerns about their potential hazards in aqueous systems (Lefevre et al. 2016).

Particulate ZVI dissolves and generates $\mathrm{Fe}^{2+}$ under acidic conditions that can facilitate P removal (Yoshino and Kawase 2013). However, the $\mathrm{Fe}^{2+}$ generation rate and resultant dosage are difficult to control during this process. As an alternative, direct current electric field-mediated oxidative dissolution of $\mathrm{Fe}$ anodes can be used to produce $\mathrm{Fe}^{2+}$ for $\mathrm{P}$ removal (Zhang et al. 2018). However, conventional electrocoagulation with $\mathrm{Fe}$ anodes requires electrical energy consumption. As a more feasible method, fuel cells have been proposed for treating acid mine drainage (Leiva et al. 2016). Based on previous reports, air-cathode fuel cells have been widely used to convert $\mathrm{Fe}^{2+}$ or $\mathrm{Fe}$ anode to $\mathrm{Fe}$ oxides (Cheng et al. 2011; Zhai et al. 2013; Kim et al. 2015). In these studies, utilization of the Fe oxide was the main concern, whereas $\mathrm{Fe}^{2+}$ was neglected. Although ironair fuel cells can be used to treat synthetic arsenate wastewater (Kim et al. 2017), the efficacy for $P$ removal is still unknown.

This study (1) assessed the $\mathrm{P}$ removal performance of in situ $\mathrm{Fe}^{2+}$ under different conditions compared with Fe salts, (2) identified the electricity generation characteristics of iron-air fuel cells, and (3) explored the $\mathrm{P}$ removal mechanism of in situ $\mathrm{Fe}^{2+}$.

\section{Material and Methods}

\section{Iron-Air Fuel Cell Setup}

A single-chamber fuel cell with $1 \mathrm{~L}$ of a circulating synthetic solution was used for in situ $\mathrm{Fe}^{2+}$ generation (Fig. 1). The surface area of the electrode plates and the chamber volume were $50 \mathrm{~cm}^{2}$ and $300 \mathrm{~mL}$, respectively. The anode was placed at one end of the chamber and covered with a plastic end plate, and the cathode was placed at the other end and covered with a second end plate with a hole in the center $(5 \mathrm{~cm})$. The electrodes were connected by titanium wires ( $1 \mathrm{~mm}$ diameter). In addition, a $\mathrm{Ag} / \mathrm{AgCl}$ reference electrode was used to measure the cathodic and anodic potentials. The potentials reported here were relative to the potential of the $\mathrm{Ag} / \mathrm{AgCl}$ reference electrode. The Fe anode consisted of a 0.30 -mm-thick plate of $\mathrm{Fe}$ (purity $99.5 \%$ ). The cathode was an air cathode manufactured based on Cheng et al. (2006). 


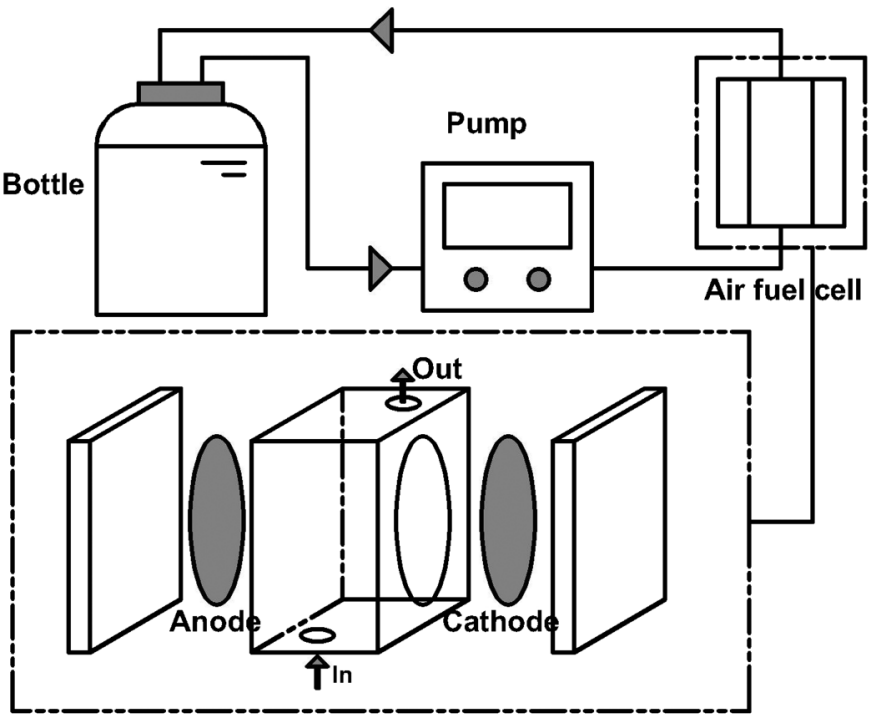

Fig. 1. Schematic of the experimental system.

\section{Synthetic P-Containing Wastewater Preparation and Experimental Operation}

Synthetic P-containing wastewater (referred to herein as $\mathrm{P}$ wastewater) was prepared with ultrapure water containing $\mathrm{NaCl}$ and $\mathrm{KH}_{2} \mathrm{PO}_{4}$. Four kinds of $\mathrm{P}$ wastewater had the same $\mathrm{NaCl}$ concentration $(500 \mu \mathrm{M})$ and different $\mathrm{KH}_{2} \mathrm{PO}_{4}$ concentrations $(100,500$, $1,000$, and $10,000 \mu \mathrm{M})$. The $\mathrm{PO}_{4}^{3-}$ concentration in $\mathrm{P}$ wastewater was analyzed prior to use.

In the fuel cell experiments, different concentrations of $\mathrm{P}$ wastewater were held in an external covered container and circulated through the reactor for 4-72 h using a peristaltic pump (flow rate $0.5 \mathrm{~L} / \mathrm{min}$ ). The fuel cell was operated in the open circuit mode for 5 min to measure the open circuit voltage of the anode and cathode, and then the titanium wires in the reactor were connected to an external resistance of $10 \Omega$. The electrode potentials and cell voltages were measured with a multimeter every $5 \mathrm{~min}$. Samples consisting of $1 \mathrm{~mL}$ solution were taken from the external reservoir at each sampling time. Based on the different initial $\mathrm{PO}_{4}^{3-}$ concentrations $(100-10,000 \mu \mathrm{M})$ and circulation times $(4-72 \mathrm{~h})$, the sampling intervals were $15,30,60$, and $120 \mathrm{~min}$, respectively.

In addition, the $\mathrm{P}$ wastewater containing $0.05 \mathrm{mM} \mathrm{NaCl}$, and $500 \mu \mathrm{M} \mathrm{KH}{ }_{2} \mathrm{PO}_{4}$ was used for contrast experiments with $\mathrm{FeSO}_{4}$ and $\mathrm{FeCl}_{3}$. In the unadjusted $\mathrm{pH}$ experiment, $1 \mathrm{~L} \mathrm{P}$ wastewater was added to each beaker, and then $250 \mu \mathrm{mol} \mathrm{FeSO}$ or $\mathrm{FeCl}_{3}$ was added every $30 \mathrm{~min}$ with stirring $(10 \mathrm{~min})$ and precipitation (20 min). During the process, the $\mathrm{pH}$ value variations were observed to investigate the effects of acidity. In the adjusted $\mathrm{pH}$ experiment, $250 \mu \mathrm{mol} \mathrm{FeSO}$ or $\mathrm{FeCl}_{3}$ was added every $30 \mathrm{~min}$ and $\mathrm{HCl}(4 \mathrm{M})$ or $\mathrm{NaOH}(4 \mathrm{M})$ were used to adjust the solution $\mathrm{pH}$ to 8 before stirring (10 min) and precipitation $(20 \mathrm{~min})$. The $\mathrm{PO}_{4}^{3-}$ in the supernatant was determined. Because the fuel cell was not an oxygen-free system, a contrast experiment was conducted under anoxic conditions (dissolved oxygen $=1.5 \pm 0.5 \mathrm{mg} / \mathrm{L}$ ).

\section{Measurement and Analysis}

The $\mathrm{PO}_{4}^{3-}$ in samples was measured using the molybdenum blue spectrophotometric method after vacuum filtration or syringe-driven filtration $(0.45-\mu \mathrm{m}$ membrane, detection limit $=0.01 \mathrm{mg} / \mathrm{L})$ (Baird et al. 2017). The $\mathrm{Fe}^{2+}$ and total Fe were measured using the 1,10-phenanthroline method (detection limit $=0.01 \mathrm{mg} / \mathrm{L}$ ).
The filter membrane containing the retained solids was vacuum cold-dried to avoid potential oxidation of $\mathrm{Fe}^{2+}$. These dried solid substances were analyzed by X-ray diffraction (XRD) and X-ray photoelectron spectroscopy (XPS). XRD data were recorded using an X-ray diffractometer (XRD-7000, Shimadzu, Kyoto, Japan) with $\mathrm{Cu}-\mathrm{K} \alpha$ radiation of $40 \mathrm{kV}$ and $30 \mathrm{~mA}$ in the $2 \theta$ range $10^{\circ}-90^{\circ}$. The scanning speed was $4.0^{\circ} / \mathrm{min}$. The valence states of $\mathrm{P}$ and $\mathrm{Fe}$ were measured with an ESCALAB 250XI X-ray photoelectron spectrometer (Thermo Scientific, Waltham, Massachusetts).

The cell potential was calculated as the difference between the anode and cathode. The current density and power density were calculated according to the following equations:

$$
\begin{gathered}
i=10000 \mathrm{~V} /(R A) \\
P_{c}=1000 \mathrm{i} \mathrm{V}
\end{gathered}
$$

where $i, V, R, A$, and $P_{c}=$ current density $\left(\mathrm{mA} / \mathrm{m}^{2}\right)$, voltage $(\mathrm{mV})$, external resistance $(\Omega)$, anode surface area $\left(\mathrm{cm}^{2}\right)$, and cell power density $\left(\mathrm{mW} / \mathrm{m}^{2}\right)$, respectively.

The generation of $\mathrm{Fe}^{2+}$ in the cells was determined by Faraday's law, and the $\mathrm{Fe}^{2+}$ generation in the fuel cell experiments was considered as the accumulated Fe dosage (Zhang et al. 2018). Therefore the accumulated $\mathrm{Fe}$ dosage was calculated as follows:

$$
C_{F e}=\frac{1000 t \sum_{0}^{n} U_{i}}{R Z F v}
$$

where $C_{F e}, t, n, U_{i}$, and $R=$ accumulated Fe dosage $(\mu \mathrm{M})$, sampling interval time (s), sampling time, external voltage $(\mathrm{mV})$, and external resistance $(\Omega)$, respectively; $Z=$ number of electrons used (for $\mathrm{Fe}, Z=2) ; F=$ Faraday's constant $(96,485 \mathrm{C} / \mathrm{mol}$ ); and $v=$ volume of solution $(1 \mathrm{~L})$.

The P removal efficiency $\left(R_{e}\right)$ and Fe utilization efficiency $\left(\eta_{F e}\right)$ were determined as follows:

$$
\begin{gathered}
R_{e}=\frac{C_{0}-C_{t}}{c_{0}} \times 100 \% \\
\eta_{F e}=\frac{C_{0}-C_{t}}{C_{F e}} \times 100 \%
\end{gathered}
$$

where $C_{0}$ and $C_{t}=$ initial $\mathrm{P}$ concentration $(\mu \mathrm{M})$ and $\mathrm{P}$ concentration at sampling time $(\mu \mathrm{M})$, respectively.

\section{Results and Discussion}

\section{P Removal by In Situ $\mathrm{Fe}^{2+}$ and Fe Salts}

\section{P Removal Efficiency}

In the in situ $\mathrm{Fe}^{2+}$-generation experiments, high $\mathrm{P}$ removal (>95\%) was achieved under different initial $\mathrm{P}$ concentrations (100$10,000 \mu \mathrm{M}$ ) studied [Fig. 2(a)]. After treatment, the $\mathrm{PO}_{4}^{3-}$ concentration in the effluent was lower than $0.2 \mathrm{mg} / \mathrm{L}$. In the in situ process, $\mathrm{Fe}^{2+}$ release was an important factor for $\mathrm{P}$ removal, and the $\mathrm{Fe}^{2+}$ concentration in solution was dependent on the total passage of the electron charge through the solution. A higher initial $\mathrm{P}$ concentration required a larger $\mathrm{Fe}^{2+}$ dosage, and according to Eq. (3), it needed more reaction time.

Different initial $\mathrm{P}$ concentrations affected $\mathrm{Fe}$ utilization efficiency [Fig. 2(b)]. In the process of P removal, Fe utilization efficiency first increased and then decreased with $\mathrm{Fe}^{2+}$ 

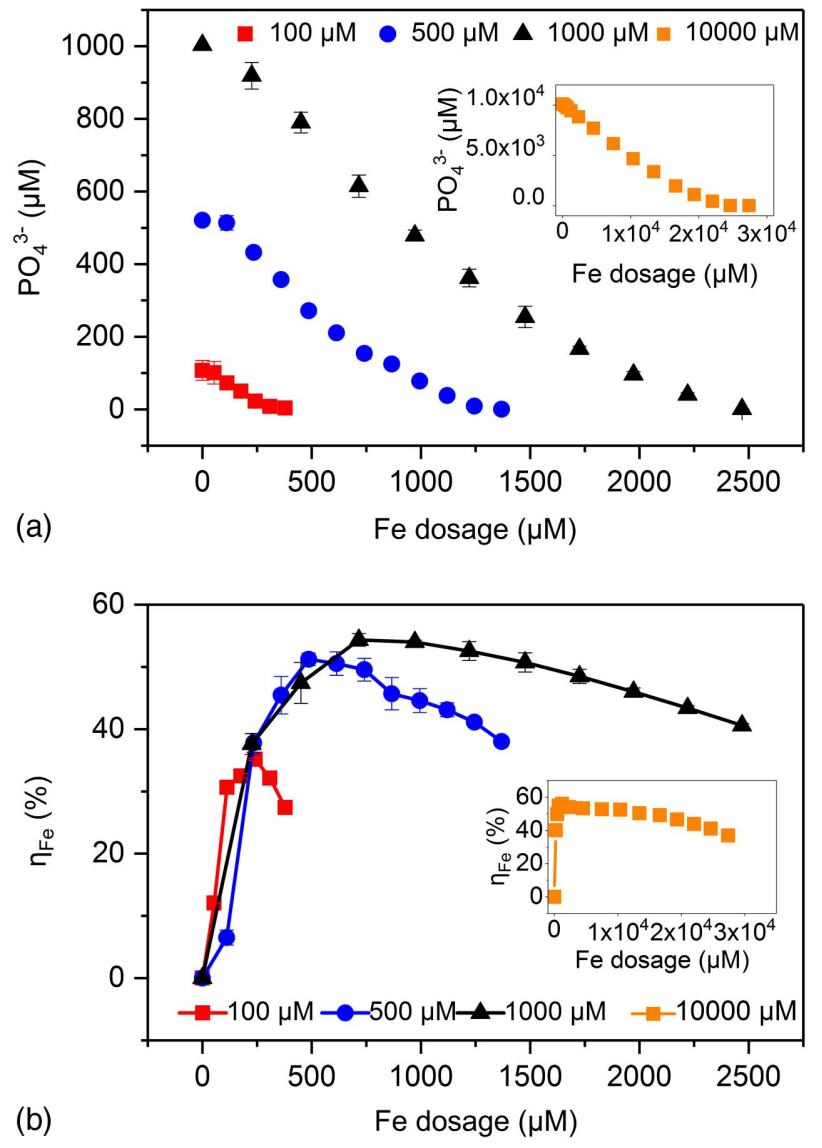

Fig. 2. Changes with the accumulated $\mathrm{Fe}$ dosage of (a) residual $\mathrm{PO}_{4}^{3-}$; and (b) $\eta_{F e}$.

accumulation. In the dynamic system of iron fuel cells, $\mathrm{Fe}^{2+}$ was continually injected and was subsequently involved in solid phase formation. At the beginning of the reaction, the accumulated $\mathrm{Fe}^{2+}$ dosage stayed at a low level, and the reaction rate of $\mathrm{PO}_{4}^{3-}$ and $\mathrm{Fe}^{2+}$ was limited by $\mathrm{Fe}^{2+}$ availability. However, as $\mathrm{Fe}^{2+}$ accumulated, the P removal efficiency increased [Fig. 2(a)]. When the accumulated amount of $\mathrm{Fe}^{2+}$ reached approximately $500 \mu \mathrm{M}$, Fe utilization efficiency decreased, indicating that a threshold of $\mathrm{Fe}^{2+}$ existed in the reaction. During the reaction, the $\mathrm{Fe}^{2+}$ released from the Fe anode exceeded an appropriate concentration (or surplus), restraining $\mathrm{Fe}$ utilization. These phenomena confirmed that $\mathrm{P}$ removal by $\mathrm{Fe}^{2+}$ was a dynamic unbalanced reaction (Zhang et al. 2013), which is explained partly by the requirement for a higher residual $\mathrm{Fe}^{2+}$ concentration to obtain a lower concentration of residual $\mathrm{PO}_{4}^{3-}$ in the solution, and partly because the generation of $\mathrm{Fe}(\mathrm{OH})_{2}$ precipitation consumed $\mathrm{Fe}^{2+}$.

In wastewater with an initial P concentration of $100 \mu \mathrm{M}, \mathrm{Fe}$ utilization efficiency reached a maximum (35\%) after Fe accumulated to a concentration of $250 \mu \mathrm{M}$. When the initial $\mathrm{P}$ increased to $10,000 \mu \mathrm{M}$, the maximum $\mathrm{Fe}$ utilization efficiency changed to $53 \%$. When the initial $\mathrm{P}$ was low $(<1,000 \mu \mathrm{M})$, the maximum Fe utilization efficiency increased with the initial P increase (Fig. 3). There was a nonlinear positive correlation between the maximum $\eta_{F e}$ and the initial $\mathrm{P}$ concentration, and a maximum $\eta_{F e}$ less than $60 \%$ meant that the Fe/P molar ratio was more than 1.5. According to Eq. (6) (Wilfert et al. 2015), if the dephosphorization process consists only of the formation of ferrous phosphate, the ratio of Fe to $\mathrm{P}$ should be close to 1.5 . This result $(\mathrm{Fe} / \mathrm{P}>1.5)$ showed that the reaction between $\mathrm{PO}_{4}^{3-}$ and $\mathrm{Fe}^{2+}$ not only generated ferrous

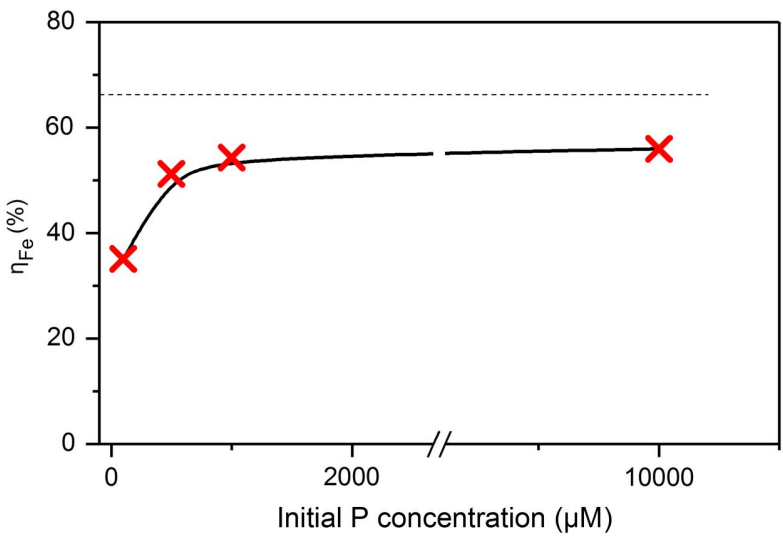

Fig. 3. Relationship between the maximum $\eta_{F e}$ and initial $\mathrm{P}$ concentrations.

phosphate but also was accompanied by the oxidation-hydrolysis of $\mathrm{Fe}^{2+}$ and dissolved $\mathrm{Fe}\left(\mathrm{Fe}^{2+}\right.$ and $\left.\mathrm{Fe}^{3+}\right)$. Additionally, the maximum $\eta_{F e}$ decreased with decreasing initial $\mathrm{P}$ concentration, indicating that an excessive amount of $\mathrm{Fe}^{2+}$ was required at a low initial $\mathrm{P}$. Therefore, in the actual application process, for low-P sewage, $\mathrm{P}$ enrichment should be conducted prior to treatment by this way

$$
3 \mathrm{Fe}^{2+}+2 \mathrm{PO}_{4}^{3-} \rightarrow \mathrm{Fe}_{3}\left(\mathrm{PO}_{4}\right)_{2} K_{\mathrm{sp}}=10^{-36}
$$

In contrast, in experiments with Fe salts, a high $\mathrm{P}$ removal rate was observed with in situ $\mathrm{Fe}^{2+}$ and $\mathrm{FeCl}_{3}$ compared with $\mathrm{FeSO}_{4}$ [Fig. 4(a)]. Zhang et al. (2018) used this result to justify the P removal efficiency achieved by in situ $\mathrm{Fe}^{2+}$ generation, which was higher than the $\mathrm{P}$ removal efficiency achieved with the addition of $\mathrm{FeSO}_{4}$. This result was related to the different $\mathrm{pH}$ values used in the in situ and salt-dosing cases. When the final $\mathrm{pH}$ of the $\mathrm{FeSO}_{4}$ dosage was adjusted to close to the in situ $\mathrm{Fe}^{2+}$ dosage $(\mathrm{pH} 8)$, the residual $\mathrm{PO}_{4}^{3-}$ concentration was significantly reduced, indicating that further comparisons need to be made under the same $\mathrm{pH}$ conditions.

Furthermore, in the case of adjusting the final $\mathrm{pH}$ to $8, \eta_{F e}$ of $\mathrm{FeSO}_{4}$ increased but the maximum value remained at a low level compared with in situ $\mathrm{Fe}^{2+}$ [Fig. 4(b)]. $\mathrm{Fe}^{2+}$ from Fe salt was mostly in the form of hydrated ions, which cannot directly react with $\mathrm{PO}_{4}^{3-}$. Flocs generated by $\mathrm{Fe}^{2+}$ hydrolysis poorly adsorb $\mathrm{PO}_{4}^{3-}$ (Wilfert et al. 2015). By contrast, the in situ $\mathrm{Fe}^{2+}$ released by the electrode was more likely to react with $\mathrm{PO}_{4}^{3-}$ prior to hydrolysis. Therefore, the results suggested that the activity of in situ $\mathrm{Fe}^{2+}$ was higher than $\mathrm{Fe}^{2+}$ from $\mathrm{FeSO}_{4}$.

\section{Variations of $\mathbf{p H}$}

Different Fe dosing patterns had different effects on the solution $\mathrm{pH}$, which, in turn, affected the $\mathrm{P}$ removal. Due to continuous in situ dosing of $\mathrm{Fe}^{2+}$, the final $\mathrm{pH}$ significantly increased compared to the initial $\mathrm{pH}$ (Table 1). These results can be explained by reactions at the anode and cathode. At the anode, Fe was converted to $\mathrm{Fe}^{2+}$ by the loss of two electrons. The electron acceptors were water and dissolved oxygen, which diffused from the air cathode into the solution. These reactions required two electron transfers to produce $\mathrm{OH}^{-}$or deplete $\mathrm{H}^{+}$, accompanied by the production of $\mathrm{Fe}^{2+}$ in the aqueous phase

$$
\begin{aligned}
& \mathrm{Fe}+2 \mathrm{H}_{2} \mathrm{O} \rightarrow \mathrm{Fe}^{2+}+\mathrm{H}_{2}+2 \mathrm{OH}^{-} \\
& \mathrm{Fe}+2 \mathrm{H}^{+}+1 / 2 \mathrm{O}_{2} \rightarrow \mathrm{Fe}^{2+}+\mathrm{H}_{2} \mathrm{O}
\end{aligned}
$$



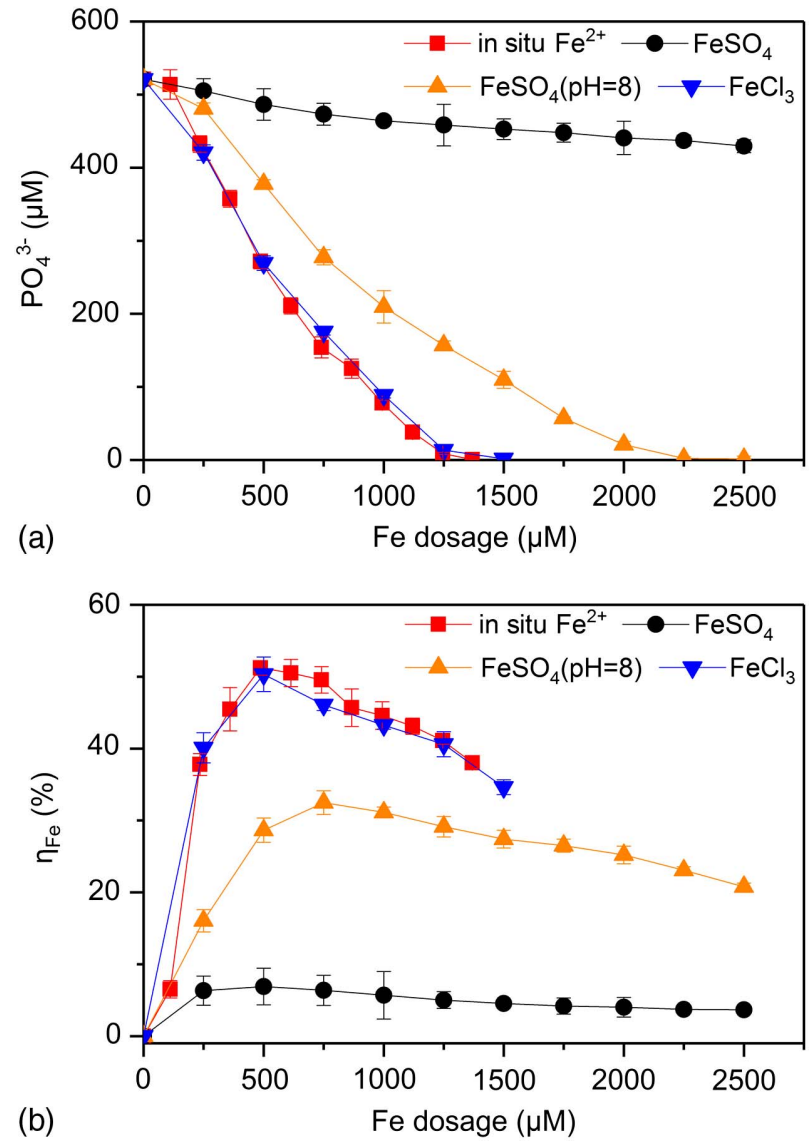

Fig. 4. $\mathrm{P}$ removal by in situ $\mathrm{Fe}^{2+}$ and $\mathrm{Fe}$ salts: (a) residual $\mathrm{PO}_{4}^{3-}$; and (b) $\eta_{F e}$

However, in the experiments in which Fe salts were added, the hydrolysis reduced the solution pH. Park et al. (2016) reported that the reduction in $\mathrm{pH}$ was not conspicuous after dosing with Fe salts because the low initial $\mathrm{P}$ concentration $(<200 \mu \mathrm{M})$ required a lower dosage of Fe salts. However, the $\mathrm{pH}$ significantly decreased at a high $\mathrm{Fe}$ salt dosage. Furthermore, a flocculent precipitate existed as the $\mathrm{pH}$ was adjusted to 8 in the experiments with $\mathrm{FeSO}_{4}$ added and changed gradually from light green to reddish brown, indicating that part of the $\mathrm{Fe}^{2+}$ had been converted to $\mathrm{Fe}^{3+}$.

In this work, the $\mathrm{pH}$ effects on $\mathrm{Fe}^{2+}$ on $\mathrm{P}$ removal had three main factors: (1) the oxidation rate of $\mathrm{Fe}^{2+}$; (2) the solubility of ferrous phosphate; and (3) the side reactions of $\mathrm{Fe}^{2+}$ hydrolysis. Zhang et al. (2013) found an approximately 100 fold increase in the $\mathrm{Fe}^{2+}$ oxidation reaction for an increase of one $\mathrm{pH}$ unit. The increase in the $\mathrm{Fe}^{2+}$ oxidation rate could effectively improve the $\mathrm{P}$ removal efficiency ( $\mathrm{Li}$ et al. 2009). Generally, the suitable $\mathrm{pH}$ range for the minimum solubility of ferrous phosphate is from 8.0 to 10.0 (Liu et al. 2018). When the $\mathrm{pH}$ deviates from this range, ferrous phosphate precipitation is reduced, resulting in a lower $\mathrm{P}$ removal efficiency. In addition, the ferrous phosphate precipitation process usually is accompanied by $\mathrm{Fe}$ hydroxide or ferrous hydroxide precipitates. With the $\mathrm{pH}$ increase, the $\mathrm{Fe}^{2+}$ and $\mathrm{Fe}^{3+}$ hydrolysis degrees is enhanced. However, the hydroxyl ion competing with $\mathrm{P}$ for Fe ions might result in a lower $\mathrm{P}$ removal efficiency when the $\mathrm{pH}$ exceeds these limits.

\section{Filterable Fe}

Fe ion $\left(\mathrm{Fe}^{2+}\right.$ and $\left.\mathrm{Fe}^{3+}\right)$ coagulation and precipitation in the water phase are prerequisites for $\mathrm{P}$ removal. Solution samples were taken at the designated times during the contrast experiments, and the filterable $\mathrm{Fe}$ was measured after collection of a filter sample through a $0.45-\mu \mathrm{m}$ membrane filter. The filterable Fe concentration during in situ $\mathrm{Fe}^{2+}$ release and the addition of $\mathrm{Fe}$ salts varied (Fig. 5). In the case of in situ $\mathrm{Fe}^{2+}$ dosing, the filterable Fe concentration was $27 \mu \mathrm{M}$ at an accumulated Fe dosage of $235 \mu \mathrm{M}$, and it increased to $56 \mu \mathrm{M}$ as the accumulated Fe increased to $487 \mu \mathrm{M}$. However, the filterable Fe decreased to $12 \mu \mathrm{M}$ when the accumulated $\mathrm{Fe}$ increased to $1,370 \mu \mathrm{M}$. These results indicated that over $95 \%$ of the $\mathrm{Fe}^{2+}$ released by the electric field existed in a solid precipitate form.

Compared with in situ $\mathrm{Fe}^{2+}$, filterable Fe increased with $\mathrm{Fe}$ accumulation upon $\mathrm{FeSO}_{4}$ dosing, in which most of the $\mathrm{Fe}^{2+}$ passed through the filters at the different Fe accumulation levels. The formation of the $\mathrm{Fe}^{2+}$ solid phase was limited under this condition $(\mathrm{pH}<7)$. The dissolved $\mathrm{Fe}^{2+}$ accounted for $90 \%$ of the total filterable $\mathrm{Fe}$ because the $\mathrm{Fe}^{2+}$ oxidation rate at this $\mathrm{pH}$ range was relatively slow (Li et al. 2009) (Fig. 4). However, after adjusting the solution $\mathrm{pH}$ to 8 , filterable Fe was appreciably reduced and was accompanied by an improvement of the $\mathrm{P}$ removal efficiency. This result confirmed that $\mathrm{Fe}$ ion precipitation in aqueous solutions is a prerequisite for $\mathrm{P}$ removal.

Initially, the filterable $\mathrm{Fe}$ during $\mathrm{FeCl}_{3}$ dosing was the lowest in all cases, which likely was caused by the high hydrolysis rate and precipitate formation rates of $\mathrm{Fe}^{3+}$ at circumneutral $\mathrm{pH}$. However, with $\mathrm{Fe}^{3+}$ accumulation and hydrolysis, a substantial $\mathrm{pH}$ decline could hinder the subsequent precipitate formation. Hence, the filterable $\mathrm{Fe}$ increased with $\mathrm{FeCl}_{3}$ continuous accumulation and was composed mostly of $\mathrm{Fe}^{3+}$. Generally, filterable $\mathrm{Fe}$ was either dissolved or present as small colloids. Dissolved Fe was expected to be almost $100 \% \mathrm{Fe}^{2+}$ because of the low solubility of $\mathrm{Fe}^{3+}$ at circumneutral $\mathrm{pH}$. However, substantial $\mathrm{Fe}^{3+}$ was present in all samples, likely due to the passage of colloidal $\mathrm{Fe}^{3+}$ and unavoidable oxidation of a small amount of $\mathrm{Fe}^{2+}$.

\section{Characteristics of Iron-Air Fuel Cell}

In the iron-air fuel cell experiment with an external resistance of 10 $\Omega$, the cell voltage was variable, and the instant potential decreased rapidly from 1.1 to $0.94 \mathrm{~V}$ in $0.5 \mathrm{~h}$ [Fig. 6(a)]. Then the voltage gradually decreased to $0.87 \mathrm{~V}$ within $24 \mathrm{~h}$. The Fe anode potential remained at $-0.6 \mathrm{~V}$ for $24 \mathrm{~h}$. However, the cathode potential decreased over time, which probably was related to cell voltage

Table 1. Variations of $\mathrm{pH}$ after in situ $\mathrm{Fe}$ or Fe salts dosing

\begin{tabular}{|c|c|c|c|c|c|c|}
\hline \multirow[b]{2}{*}{ Parameter } & \multicolumn{6}{|c|}{ Initial $\mathrm{PO}_{4}^{3-}$ concentration $(\mu \mathrm{M})$} \\
\hline & 107.3 & 521 & 521 & 521 & $1,003.5$ & 10,112 \\
\hline Fe dosage $(\mu \mathrm{M})$ & 378.7 & $1,369.5$ & $2,500\left(\mathrm{FeSO}_{4}\right)$ & $1,500\left(\mathrm{FeCl}_{3}\right)$ & $2,469.2$ & 27,392 \\
\hline Initial $\mathrm{pH}$ & 6.87 & 5.40 & 5.40 & 5.40 & 5.23 & 4.73 \\
\hline Final pH & 7.61 & 8.2 & 4.94 & 2.96 & 8.56 & 9.42 \\
\hline
\end{tabular}




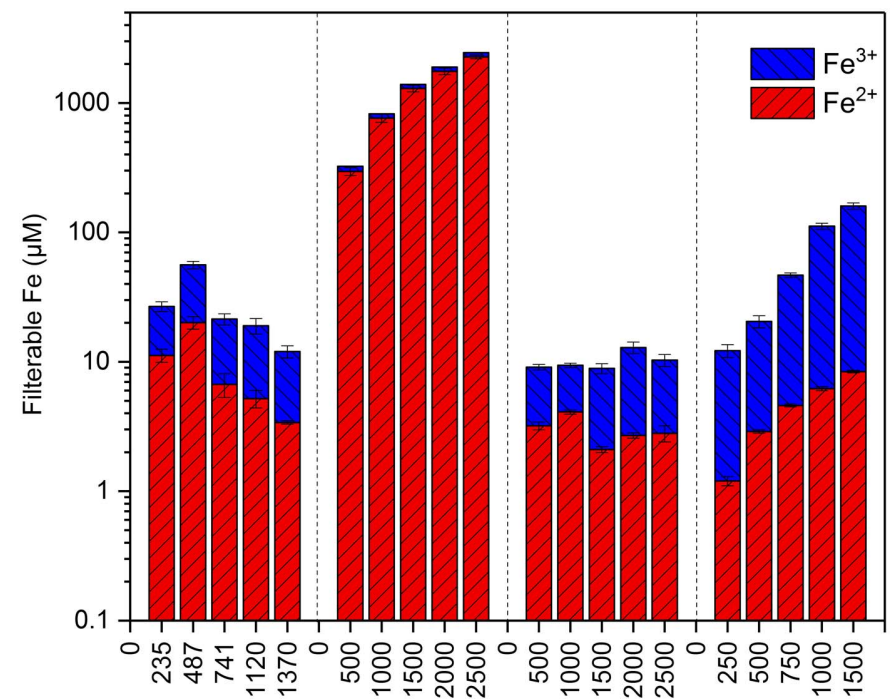

(a)

(b)

(c)

(d)

Accumulated Fe dosage $(\mu \mathrm{M})$

Fig. 5. Filterable $\mathrm{Fe}$ during continuous dosing of in situ $\mathrm{Fe}^{2+} / \mathrm{Fe}$ salts: (a) in situ $\mathrm{Fe}$; (b) $\mathrm{FeSO}_{4}, \mathrm{pH}$ unadjusted; (c) $\mathrm{FeSO}_{4}, \mathrm{pH}$ adjusted to 8; and (d) $\mathrm{FeCl}_{3}, \mathrm{pH}$ unadjusted.

reduction. The anode potential might decrease over time due to the Eq. (9) and (10) in the Fe anode (Eliyan et al. 2015)

$$
\begin{gathered}
\mathrm{Fe}(\mathrm{OH})_{2}+\mathrm{OH}^{-} \rightarrow \mathrm{Fe}(\mathrm{OH})_{3}+\mathrm{e}^{-} \\
\mathrm{Fe}(\mathrm{OH})_{2}+\mathrm{OH}^{-} \rightarrow \mathrm{FeOOH}+\mathrm{H}_{2} \mathrm{O}+\mathrm{e}^{-} \\
2 \mathrm{Fe}(\mathrm{OH})_{3}+\mathrm{Fe}^{2+} \rightarrow \mathrm{Fe}_{3} \mathrm{O}_{4}+2 \mathrm{H}_{2} \mathrm{O}+\mathrm{H}^{+} \\
2 \mathrm{FeOOH}+\mathrm{Fe}(\mathrm{OH})_{2} \rightarrow \mathrm{Fe}_{3} \mathrm{O}_{4}+2 \mathrm{H}_{2} \mathrm{O}
\end{gathered}
$$

In these reactions, a passivation layer forms on the $\mathrm{Fe}$ anode, which may affect the cell potential stability and the P removal efficiency. However, in this study, a passivation layer of Fe hydroxide formed on the anode and then shed continually due to the sustained reaction between the electrolyte and the anode surface. The anode potential was constant during the process, indicating that Eqs. (11) and (12) occurred. Namely, $\mathrm{Fe}^{2+}$ in the aqueous phase prevented the formation of passive Fe hydroxide films, and Fe oxide formation in the aqueous phase was induced via reactions between $\mathrm{Fe}$ hydroxide on the anode surface and $\mathrm{Fe}^{2+}$ in the electrolyte. For the cathode, the initial actual potential $(0.48 \mathrm{~V})$ was lower than the theoretical value $(0.804 \mathrm{~V})$ under standard conditions, indicating that further improvements in the cathode performance were possible (Liu and Logan 2004).

Power density versus current density curves are shown in Fig. 6(b). The maximum power density was $1,875 \mathrm{~mW} / \mathrm{m}^{2}$, which was different from previous reports (Cheng et al. 2007; Kim et al. 2015). This maximum power density difference could be a result of multiple factors. First, changing the electrolyte increased the ionic strength in the system and induced a smaller internal resistance. The small internal resistance could result in observed increases in the working potentials. Second, the Pt catalyst on the cathode increased the efficiency of the oxygen reduction reaction. Third, $\mathrm{NaCl}$ affected the cell reaction. However, previous reports suggested that the effects of $\mathrm{NaCl}$ on the power production had both positive (increasing the ionic strength) and negative (hindered $\mathrm{Pt}$ catalyst performance) factors (Wang et al. 2011; Kim et al. 2015).
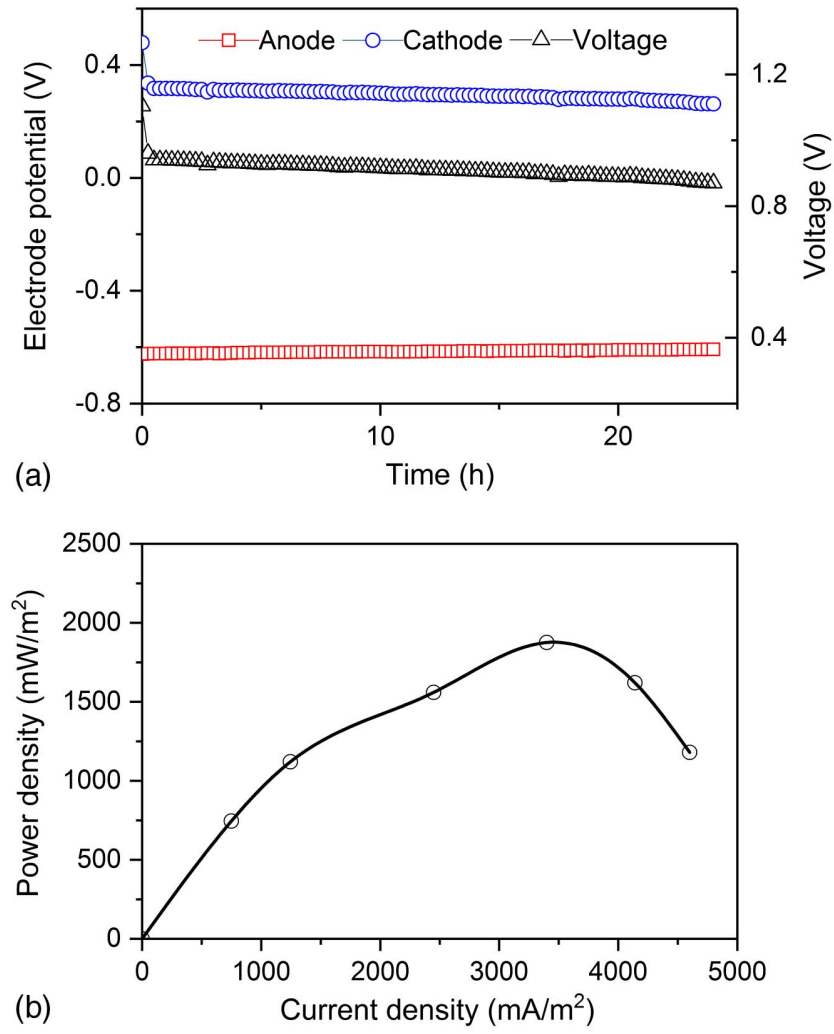

Fig. 6. Characteristics of the iron fuel cell: (a) electrode potentials; and (b) power density versus current density curves.

Thus, we determined that the increase in the working potential was the most likely explanation for the maximum power density difference.

The iron-air fuel cells maintained a stable output power over $24 \mathrm{~h}$. Although the current can be adjusted by the external resistance, a large current may improve the formation rate of in situ $\mathrm{Fe}^{2+}$, leading to fluctuation of the electrode potential. Therefore, a suitable current density $\left(1,245-3,400 \mathrm{~mA} / \mathrm{m}^{2}\right)$ for stable $\mathrm{Fe}^{2+}$ generation is preferred for the $\mathrm{P}$ removal process.

\section{Mechanisms and Applicability}

\section{Main Removal Mechanism}

During the reaction process, the solution changed from colorless to light green because of $\mathrm{Fe}^{2+}$ production. At the beginning of the reaction, the $\mathrm{Fe}$ anode was oxidized to $\mathrm{Fe}^{2+}$ and then reacted with $\mathrm{PO}_{4}^{3-}$. Three reactions may have occurred: (1) ferrous phosphate precipitated from $\mathrm{Fe}^{2+}$ and $\mathrm{PO}_{4}^{3-}$, i.e., vivianite; (2) $\mathrm{Fe}^{2+}$ was transformed into ferrous hydroxide by hydrolysis, i.e., during hydrolysis a portion of the hydrolytic products underwent chemical adsorption with $\mathrm{PO}_{4}^{3-}$ to form coprecipitates of phosphate and ferrous hydroxide; and (3) a portion of $\mathrm{Fe}^{2+}$ was oxidized into $\mathrm{Fe}^{3+}$, and the amorphous $\mathrm{Fe}$ oxide produced enhanced $\mathrm{PO}_{4}^{3-}$ removal by physical and chemical adsorption during hydrolysis. Because the $\mathrm{pH}$ in this study was close to neutral, the formation of ferric phosphate by $\mathrm{Fe}^{3+}$ and $\mathrm{PO}_{4}^{3-}$ was not considered (Smith et al. 2008; Zhang et al. 2010).

Compared with dosing with $\mathrm{FeSO}_{4}$, the high $\mathrm{Fe}^{2+}$ reactivity and $\mathrm{pH}$ of the in situ $\mathrm{Fe}^{2+}$ system may result in a higher formation rate of ferrous phosphate than hydrated $\mathrm{Fe}^{2+}\left(\mathrm{FeSO}_{4}\right)$. However, limited by the oxygen mass transfer rate of the air cathode, the 


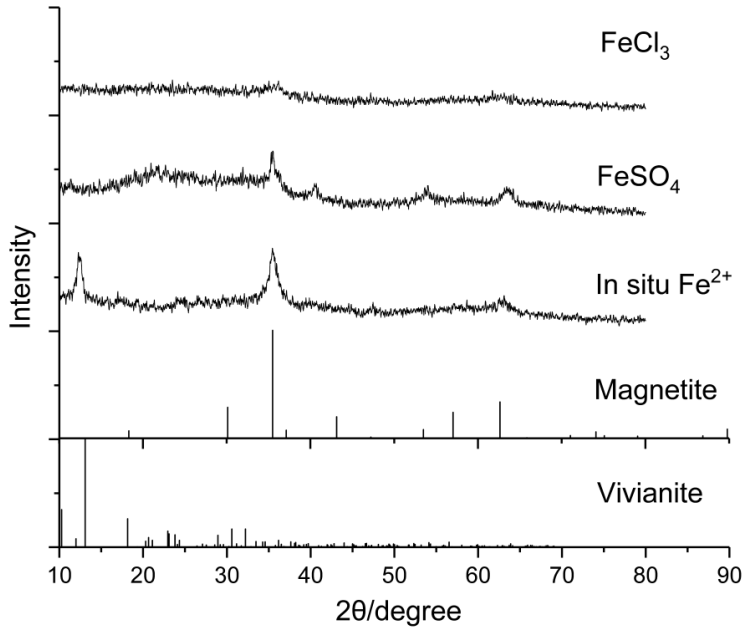

Fig. 7. XRD patterns of the precipitated solids.

transformation from $\mathrm{Fe}^{2+}$ into $\mathrm{Fe}^{3+}$ faced some restrictions (Liu and Logan 2004). The XRD patterns of the $\mathrm{P}$ product removed by $\mathrm{FeSO}_{4}$ indicated that the solid phase contained amorphous substances (Fig. 7). Presumably, the solid products were composed mainly of coprecipitation products and amorphous $\mathrm{Fe}$ oxides with $\mathrm{PO}_{4}^{3-}$ adsorbed. For in situ $\mathrm{Fe}^{2+} \mathrm{P}$ removal products, diffraction peaks appeared in the XRD patterns, but the peaks had a slight shift compared with the standard powder diffraction file (PDF) cards; furthermore, two obvious precipitate peaks could be indexed by compounds including vivianite (ferrous phosphate) and magnetite. Magnetite could be derived from Fe hydroxide by Eqs. (11) and (12).

Furthermore, the peak in the structure of the $\mathrm{P}(2 \mathrm{p})$ spectrum observed at a binding energy of $133.5 \mathrm{eV}$ indicated the presence of $\mathrm{PO}_{4}^{3-}$ groups [Fig. 8(a)]. Pratt (1997) interpreted this peak to be from the $\mathrm{PO}_{4}^{3-}$ component of vivianite. The $\mathrm{Fe}(2 \mathrm{p} 3 / 2)$ narrow-scan spectra were characterized by two peaks [Fig. 8(b)]; one was found near $711.6 \mathrm{eV}$ and the other near $709.9 \mathrm{eV}$. According to Bae et al. (2018), fresh vivianite exhibited peaks at $709.9 \mathrm{eV}$, which were identified as being due to $\mathrm{Fe}^{2+}$ species. The second peak was centered at $711.6 \mathrm{eV}$ and corresponded to the binding energy of $\mathrm{Fe}^{3+}$ with oxygen atoms. Thus, it was thought that the low energy contribution resulted from $\mathrm{Fe}^{2+}$, whereas the higher energy contribution resulted from $\mathrm{Fe}^{3+}$.

Previous studies used thermodynamic analysis to predict possible solid phase formation in aqueous solutions. Zhang et al. (2018) presumed that the reaction product was ferrous hydroxide, but vivianite formation was limited. In contrast, vivianite was the dominant product in the research by Liu et al. (2018). Combined with previous reports and experimental results, the dominant products in this study were vivianite and iron oxide-P complexes. Moreover, previous studies showed that kinetic limitations do not appear to influence the key reactions associated with $\mathrm{P}$ removal (Zhang et al. 2018). The $P$ removal pathway was analyzed preliminarily based on thermodynamics. Zhang et al. (2013) calculated the priority orders for precipitation of vivianite $\mathrm{Fe}(\mathrm{OH})_{2}$ according to the $K_{s p}$. When $\mathrm{pH}$ was in the range 8-9 and the $\mathrm{PO}_{4}^{3-}$ concentration was higher than $100 \mathrm{mg} / \mathrm{L}$, vivianite precipitated first. With in situ $\mathrm{Fe}^{2+}$ generation, the solubility product of $\mathrm{Fe}^{2+}$ and $\mathrm{PO}_{4}^{3-}$ was larger than the solubility product constant, and vivianite was formed. However, the metastable zone for vivianite crystallization was supersaturated index (SI) 0-11 (Liu et al. 2018). Although the SI value in this study was not specifically calculated, the SI was less
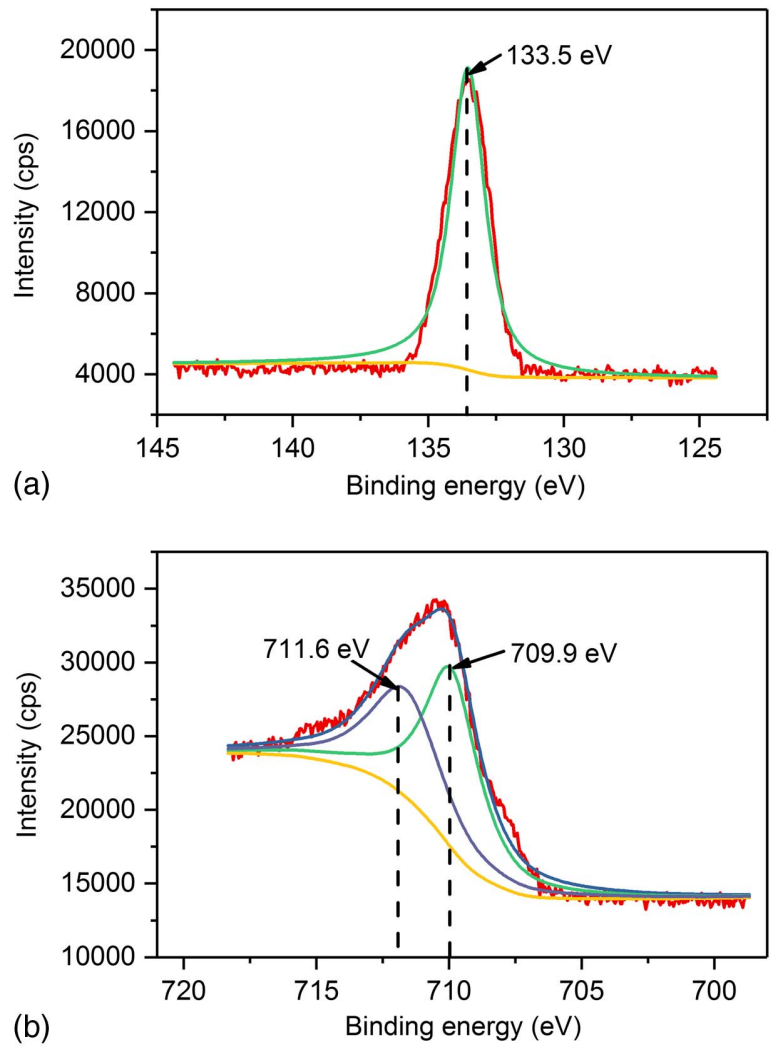

Fig. 8. XPS spectra of elemental $\mathrm{P}$ and $\mathrm{Fe}$ in the precipitate of the iron fuel cell: (a) P; and (b) Fe.

than the lower limit with $\mathrm{PO}_{4}^{3-}$ concentration decrease, and the vivianite crystallization would be inhibited. Then ferrous hydroxide could be formed with $\mathrm{P}$ removal occurring via coprecipitation and/or adsorption. As stated, the main $\mathrm{P}$ removal mechanisms by iron fuel cells were vivianite precipitation by $\mathrm{Fe}^{2+}$ and $\mathrm{PO}_{4}^{3-}$ and $\mathrm{Fe}$ oxides adsorption.

\section{Applicability Prospects}

Compared with previous studies, electrocoagulation with an ironair fuel cell is an innovative $\mathrm{P}$ removal system that can simultaneously generate electricity (Zhang et al. 2018). Although the cumulative $\mathrm{Fe}$ dosage is limited by the cell power, this problem can be solved by improving the cell power or using a stacked iron-air fuel cell. In situ $\mathrm{Fe}^{2+}$ dosing could increase the effluent $\mathrm{pH}$, and the continuous generation of alkalinity is likely to be advantageous for further processing. Moreover, the influence of other chemical components in wastewater (e.g., competitive anions or organic compounds) was an inevitable challenge in the actual treatment progress. Previous reports have shown that sulfate has a primary impact on vivianite formation because sulfate can be bonded to Fe to compete with $\mathrm{P}$ to reduce the vivianite production (Rothe et al. 2016). Clearly, adequate research was needed on the impacts of potentially interfering compounds for $\mathrm{P}$ removal before application.

Currently, the main relatively mature technical method for $\mathrm{P}$ recovery is struvite recovery (Li et al. 2019). However, some studies have shown that vivianite can be the nucleus for alternative $\mathrm{P}$ recovery options (Wilfert et al. 2018). Although P removed by fuel cells can be recovered in this form, enhancement of vivianite crystallization needs comprehensive and further understanding. In this study, the end products contained amounts of byproducts of iron precipitates. Therefore, optimization of the reaction conditions 
for a higher vivianite yield, further separation and purification of the vivianite, and feasible $\mathrm{P}$ recovery should be conducted under practical conditions. Cost reduction for the cell installation and maintenance is an inevitable problem in practical applications.

\section{Conclusions}

This study used a novel $\mathrm{Fe}^{2+}$ injection by an iron fuel cell to remove $\mathrm{PO}_{4}^{3-}$ from aqueous solutions. The $\mathrm{P}$ removal efficiency exceeded $95 \%$ with different initial $\mathrm{P}$ concentrations. In contrast to using Fe salts, after $\mathrm{P}$ removal by the air fuel cell, the main transition products of $\mathrm{P}$ were vivianite and Fe hydroxides. The output voltage of iron-air fuel cell could be kept stable over time ( $>24 \mathrm{~h})$, and the maximum power density reached $1,875 \mathrm{~mW} / \mathrm{m}^{2}$. Further studies still are needed of high-purity vivianite formation, cost reduction, and long-term experiments.

\section{Data Availability Statement}

Some or all data, models, or code that support the findings of this study are available from the corresponding author upon reasonable request.

\section{Acknowledgments}

This study was supported by the Strategic Priority Research Program of the Chinese Academy of Sciences (Grant No. XDA23050203) and the National Natural Science Foundation of China (Grant No. 41373100). Additional support was provided by the Key Project of Research and Development Plan of Yantai, Shandong Province (Grant No. 2018ZHGY083).

\section{References}

Almeelbi, T., and A. Bezbaruah. 2012. "Aqueous phosphate removal using nanoscale zero-valent iron." J. Nanopart. Res. 14 (7): 1-14. https://doi .org/10.1007/s11051-012-0900-y.

Bae, S., Y. Sihn, D. Kyung, S. Yoon, T. Eom, U. Kaplan, H. Kim, T. Schaefer, S. Han, and W. Lee. 2018. "Molecular identification of $\mathrm{Cr}$ (VI) removal mechanism on vivianite surface." Environ. Sci. Technol. 52 (18): 10647-10656. https://doi.org/10.1021/acs.est.8b01614.

Baird, R., L. Bridgewater, American Public Health Association, American Water Works Association, and Water Environment Federation. 2017. Standard methods for the examination of water and wastewater. Washington, DC: American Public Health Association.

Cheng, S., B. A. Dempsey, and B. E. Logan. 2007. "Electricity generation from synthetic acid-mine drainage (AMD) water using fuel cell technologies." Environ. Sci. Technol. 41 (23): 8149-8153. https://doi.org /10.1021/es0712221.

Cheng, S., J. H. Jang, B. A. Dempsey, and B. E. Logan. 2011. "Efficient recovery of nano-sized iron oxide particles from synthetic acid-mine drainage (AMD) water using fuel cell technologies." Water Res. 45 (1): 303-307. https://doi.org/10.1016/j.watres.2010.07.054.

Cheng, S., H. Liu, and B. E. Logan. 2006. "Increased performance of single-chamber microbial fuel cells using an improved cathode structure." Electrochem. Commun. 8 (3): 489-494. https://doi.org/10.1016/j .elecom.2006.01.010.

Conley, D. J., H. W. Paerl, R. W. Howarth, D. F. Boesch, S. P. Seitzinger, K. E. Havens, C. Lancelot, and G. E. Likens. 2009. "Ecology controlling eutrophication: Nitrogen and phosphorus." Science 323 (5917): 1014-1015. https://doi.org/10.1126/science.1167755.

Eliyan, F. F., J. R. Kish, and A. Alfantazi. 2015. "Voltammetric analysis on the formation of $\mathrm{Fe}(\mathrm{OH})_{2}$ and $\mathrm{FeCO}_{3}$, and on the reactivity of passivation of steel in carbonate solutions." J. Mater. Eng. Perform. 24 (6): 2473-2480. https://doi.org/10.1007/s11665-015-1525-y.

Kim, J. H., H. A. Maitlo, and J. Y. Park. 2017. "Treatment of synthetic arsenate wastewater with iron-air fuel cell electrocoagulation to supply drinking water and electricity in remote areas." Water Res. 115 (May): 278-286. https://doi.org/10.1016/j.watres.2017.02.066.

Kim, J. H., I. S. Park, and J. Y. Park. 2015. "Electricity generation and recovery of iron hydroxides using a single chamber fuel cell with iron anode and air-cathode for electrocoagulation." Appl. Energy 160 (Dec): 18-27. https://doi.org/10.1016/j.apenergy.2015.09.041.

Lefevre, E., N. Bossa, M. R. Wiesner, and C. K. Gunsch. 2016. "A review of the environmental implications of in situ remediation by nanoscale zero valent iron (nZVI): Behavior, transport and impacts on microbial communities." Sci. Total Environ. 565 (Sep): 889-901. https://doi.org /10.1016/j.scitotenv.2016.02.003.

Leiva, E., E. Leiva-Aravena, and I. Vargas. 2016. “Acid water neutralization using microbial fuel cells: An alternative for acid mine drainage treatment." Water 8 (11): 536. https://doi.org/10.3390/w8110536.

Li, B., I. Boiarkina, W. Yu, H. M. Huang, T. Munir, G. Q. Wang, and B. R. Young. 2019. "Phosphorous recovery through struvite crystallization: Challenges for future design." Sci. Total Environ. 648 (Jan): 1244-1256. https://doi.org/10.1016/j.scitotenv.2018.07.166.

Li, C., J. Ma, J. Shen, and P. Wang. 2009. "Removal of phosphate from secondary effluent with $\mathrm{Fe}^{2+}$ enhanced by $\mathrm{H}_{2} \mathrm{O}_{2}$ at nature $\mathrm{pH} /$ neutral pH.” J. Hazard. Mater. 166 (2-3): 891-896. https://doi.org/10.1016/j .jhazmat.2008.11.111.

Liu, H., and B. E. Logan. 2004. "Electricity generation using an air-cathode single chamber microbial fuel cell in the presence and absence of a proton exchange membrane." Environ. Sci. Technol. 38 (14): 4040-4046. https://doi.org/10.1021/es0499344.

Liu, J., X. Cheng, X. Qi, N. Li, J. Tian, B. Qiu, K. Xu, and D. Qu. 2018. "Recovery of phosphate from aqueous solutions via vivianite crystallization: Thermodynamics and influence of pH." Chem. Eng. J. 349 (Oct): 37-46. https://doi.org/10.1016/j.cej.2018.05.064.

Molinos-Senante, M., F. Hernandez-Sancho, R. Sala-Garrido, and M. Garrido-Baserba. 2011. "Economic feasibility study for phosphorus recovery processes." Ambio 40 (4): 408-416. https://doi.org/10.1007 /s13280-010-0101-9.

Park, T., V. Ampunan, S. Lee, and E. Chung. 2016. "Chemical behavior of different species of phosphorus in coagulation." Chemosphere 144 (Feb): 2264-2269. https://doi.org/10.1016/j.chemosphere.2015 .10.131.

Pratt, A. R. 1997. "Vivianite auto-oxidation." Phys. Chem. Miner. 25 (1): 24-27. https://doi.org/10.1007/s002690050082.

Ren, B., C. Li, X. Zhang, and Z. Zhang. 2019. "Fe(II)-dosed ceramic membrane bioreactor for wastewater treatment: Nutrient removal, microbial community and membrane fouling analysis." Sci. Total Environ. 664 (May): 116-126. https://doi.org/10.1016/j.scitotenv.2019.02.019.

Rothe, M., A. Kleeberg, and M. Hupfer. 2016. "The occurrence, identification and environmental relevance of vivianite in waterlogged soils and aquatic sediments." Earth Sci. Rev. 158 (Jul): 51-64. https://doi .org/10.1016/j.earscirev.2016.04.008.

Sleiman, N., V. Deluchat, M. Wazne, M. Mallet, A. Courtin-Nomade, V. Kazpard, and M. Baudu. 2016. "Phosphate removal from aqueous solution using ZVI/sand bed reactor: Behavior and mechanism." Water Res. 99 (Aug): 56-65. https://doi.org/10.1016/j.watres.2016.04.054.

Smith, S., I. Takacs, S. Murthy, G. T. Daigger, and A. Szabo. 2008. "Phosphate complexation model and its implications for chemical phosphorus removal." Water Environ. Res. 80 (5): 428-438. https://doi.org/10.1002 /j.1554-7531.2008.tb00349.x.

Wan, J., X. Jiang, T. C. Zhang, J. Hu, D. Richter-Egger, X. Feng, A. Zhou, and T. Tao. 2018. "The activated iron system for phosphorus recovery in aqueous environments." Chemosphere 196 (Apr): 153-160. https://doi .org/10.1016/j.chemosphere.2017.12.140.

Wang, X., S. Cheng, X. Zhang, X.-Y. Li, and B. E. Logan. 2011. "Impact of salinity on cathode catalyst performance in microbial fuel cells (MFCs)." Int. J. Hydrogen Energy 36 (21): 13900-13906. https://doi .org/10.1016/j.ijhydene.2011.03.052.

Wilfert, P., A. I. Dugulan, K. Goubitz, L. Korving, G. J. Witkamp, and M. C. M. Van Loosdrecht. 2018. "Vivianite as the main phosphate 
mineral in digested sewage sludge and its role for phosphate recovery." Water Res. 144 (Nov): 312-321. https://doi.org/10.1016/j.watres.2018 .07.020.

Wilfert, P., P. S. Kumar, L. Korving, G.-J. Witkamp, and M. C. M. van Loosdrecht. 2015. "The relevance of phosphorus and iron chemistry to the recovery of phosphorus from wastewater: A review." Environ. Sci. Technol. 49 (16): 9400-9414. https://doi.org/10.1021/acs.est $.5 \mathrm{~b} 00150$

Yoshino, H., and Y. Kawase. 2013. "Kinetic modeling and simulation of zero-valent iron wastewater treatment process: Simultaneous reduction of nitrate, hydrogen peroxide, and phosphate in semiconductor acidic wastewater." Ind. Eng. Chem. Res. 52 (50): 17829-17840. https://doi .org/10.1021/ie402797j.

Zhai, L.-F., Z.-H. Tong, M. Sun, W. Song, S. Jin, and H. Harada. 2013. "Enhanced electricity generation from electrochemical oxidation of $\mathrm{Fe}^{\mathrm{II}}$ in an air-cathode fuel cell amended with chelating anions." Ind. Eng. Chem. Res. 52 (6): 2234-2240. https://doi.org/10.1021/ie3032185.
Zhang, J., M. W. Bligh, P. Liang, T. D. Waite, and X. Huang. 2018. "Phosphorus removal by in situ generated Fe(II): Efficacy, kinetics and mechanism." Water Res. 136 (Jun): 120-130. https://doi.org/10.1016/j .watres.2018.02.049.

Zhang, M., K. Zheng, J. Jin, X. Yu, L. Qiu, S. Ding, H. Lu, J. Cai, and P. Zheng. 2013. "Effects of $\mathrm{Fe}(\mathrm{II}) / \mathrm{P}$ ratio and $\mathrm{pH}$ on phosphorus removal by ferrous salt and approach to mechanisms." Sep. Purif. Technol. 118 (Oct): 801-805. https://doi.org/10.1016/j.seppur.2013 .08 .034 .

Zhang, T., L. Ding, H. Ren, Z. Guo, and J. Tan. 2010. "Thermodynamic modeling of ferric phosphate precipitation for phosphorus removal and recovery from wastewater." J. Hazard. Mater. 176 (1-3): 444-450. https://doi.org/10.1016/j.jhazmat.2009.11.049.

Zhou, Y., X.-H. Xing, Z. Liu, L. Cui, A. Yu, Q. Feng, and H. Yang. 2008. "Enhanced coagulation of ferric chloride aided by tannic acid for phosphorus removal from wastewater." Chemosphere 72 (2): 290-298. https://doi.org/10.1016/j.chemosphere.2008.02.028. 